\title{
A MAGYAR HONVÉDSÉG LOGISZTIKAI KÖZPONT FOLYÓIRATAINAK SZEREPE A TUDOMÁNYOS TEVÉKENYSÉG TÁMOGATÁSÁBAN
}

\author{
DOI: $10.30583 / 2018 / 1-2 / 133$
}

\section{Összefoglaló}

Ebben a cikkben a szerzők röviden ismertetik a Honvédelmi Minisztérium által megjelentetett folyóiratok közül az MH Logisztikai Központhoz köthetö három kiadványt (Haditechnika, Katonai Logisztika és Karbantartalak), és tudománymetriai szempontok alapján részben értékelik is azokat. A tanulmány végén adminisztratív jellegü javaslatokat fogalmaznak meg (elsősorban a tulajdonos felé) annak érdekében, hogy az említett folyóiratok színvonala emelkedhessen.

Kulcsszavak: MH Logisztikai Központ, Haditechnika, Katonai Logisztika, Karbantartalak, hivatkozáskezelő programok, DOI, ORCID

\section{Abstract}

In this article, the authors briefly describe three periodicals from all papers published by the Ministry of Defence, and owned by the HDF Logistics Centre: Haditechnika - Military Technology, Katonai Logisztika - Military Logistics, and Karbantartalak - Maintenance Statements. The authors also try to evaluate these journals on the basis of scientometrics. At the end of the study, the authors formulate some administrative suggestions (primarily towards the owner) in order to increase the scientific level of these periodicals.

1 MH LK Technológiai Igazgatóság, Kutatás-fejlesztési, Tudományos és Szabványosítási Osztály, főelőadó, Haditechnika folyóirat szerkesztőasszisztens, DOI adminisztrátor. E-mail: szivak.petra@hm.gov.hu

ORCID: 0000-0002-5040-8739

Dr. Gyulai Gábor nyá. mk. ezredes (PhD), korábban a HM Fegyverzeti és Hadbiztosi Hivatal, Hadfelszerelési Igazgatóság, Haditechnikai Intézet, Kutatási és Fejlesztési Iroda, irodavezető (intézetvezető-helyettes). Az NKE Katonai Műszaki Doktori Iskola oktatója.

E-mail: gabor.gy@citromail.hu 
Keywords: HDF Logistics Centre, Haditechnika, Katonai Logisztika, Karbantartalak, reference management programs, DOI, ORCID

\section{Bevezetés}

A Honvédelmi Minisztérium a társadalommal, ezen belül saját alkalmazottjaival, illetve a tudományos szférával az általa megjelentetett folyóiratokon és könyveken keresztül (is) kommunikál. A széleskörü, többrétü kommunikáción túlmenően e kiadványok fontos feladata, hogy elsősorban a tárca alkalmazásában álló tudományos kutatókat (felsőoktatásban dolgozó oktatókat, egyetemi tanárokat, HM intézetekben alkalmazott kutatókat stb.) publikációs felülethez juttassa annak érdekében, hogy tudományos munkásságuk során lehetségessé váljon a $\mathrm{PhD}$ fokozat megszerzése, a habilitáció, illetve a DsC fokozat elnyerése is. Mindez a tárca magyar tudományos szférával való kapcsolattartása, a tudományos életben való részvétele, a tudomány szereplőivel (kutatóintézetek, egyetemek, Magyar Tudományos Akadémia) való közös tevékenység feltételeinek megteremtése érdekében is történik úgy, hogy közben a kutatási eredményeket - más kutatók segítése érdekében - elérhetővé, feldolgozhatóvá teheti.

A fentiek alapján úgy gondoljuk, hogy fontos egy ilyen tanulmány elkészítése, illetve megjelenése ezen a felületen, amely a Minisztérium kezelésében lévő, elsősorban az MH Logisztikai Központhoz (a továbbiakban: MH LK) köthető folyóiratok jellemzőit vizsgálja, elemzi.

Az 1. számú táblázatban - a teljesség igénye nélkül - rendszereztük a tárca kezelésében lévő tudományos és egyéb folyóiratokat terjesztési körük, valamint megjelenési formájuk alapján. Amint az a táblázatból látható, az MH LK tulajdonában lévő három folyóirat - a Haditechnika, a Katonai Logisztika ${ }^{3}$, illetve a Karbantartalak - a katonai folyóiratok három eltérő kategóriáját képviseli. Az első két folyóiratot a Magyar Tudományos Akadémia (MTA) IX. osztály Hadtudományi Bizottsága „B” tudományos kategóriába sorolta, aminek meghatározó jelentősége van az MH LK-nál 2017 októberében felállított tudományos kutatóhely müködtetése szempontjából is. Írásunkban az $\mathrm{MH}$ LK-hoz köthető három folyóirat általános bemutatásán túlmenően megvizsgáljuk annak lehetőségét is, hogy mi módon lehetne azok

3 50-50\%-os tulajdonmegosztásban az MH LK és a Magyar Katonai Logisztikai Egyesület között. 
színvonalát emelni. Ezzel kapcsolatos javaslatainkat a cikk végén foglaljuk össze.

\section{A KATONAI FOLYÓIRATOK RENDSZERE}

1. sz. táblázat

\begin{tabular}{|c|c|c|c|c|}
\hline $\begin{array}{l}\text { Országos } \\
\text { terjesztés }\end{array}$ & $\begin{array}{l}\text { Magyar Hon- } \\
\text { védség által } \\
\text { kiadott }\end{array}$ & \multicolumn{2}{|c|}{$\begin{array}{l}\text { Nemzeti Közszolgálati Egye- } \\
\text { tem által kiadott }\end{array}$} & \multirow{2}{*}{$\begin{array}{l}\text { Önálló - kuta- } \\
\text { tóhely státuszú } \\
\text { - szervezetek } \\
\text { által kiadott } \\
\text { nyomtatott és } \\
\text { elektronikus }\end{array}$} \\
\hline $\begin{array}{l}\text { nyomtatott és } \\
\text { elektronikus }\end{array}$ & $\begin{array}{l}\text { nyomtatott és } \\
\text { elektronikus }\end{array}$ & elektronikus & $\begin{array}{l}\text { nyomtatott és } \\
\text { elektronikus }\end{array}$ & \\
\hline $\begin{array}{l}\text { Magyar Hon- } \\
\text { véd }\end{array}$ & $\begin{array}{l}\text { Honvédségi } \\
\text { Szemle }\end{array}$ & $\begin{array}{l}\text { Hadtudomá- } \\
\text { nyi Szemle }\end{array}$ & Bolyai Szemle & $\begin{array}{l}\text { Katonai Lo- } \\
\text { gisztika }\end{array}$ \\
\hline \multirow[t]{3}{*}{ Haditechnika } & Seregszemle & Hadmérnök & AARMS & Honvédorvos \\
\hline & $\begin{array}{l}\text { Honvéd Altiszti } \\
\text { Folyóirat }\end{array}$ & $\begin{array}{l}\text { Repüléstudo- } \\
\text { mányi Köz- } \\
\text { lemények }\end{array}$ & & $\begin{array}{l}\text { Felderítő } \\
\text { Szemle }\end{array}$ \\
\hline & Karbantartalak & $\begin{array}{l}\text { Nemzet és } \\
\text { Biztonság }\end{array}$ & & $\begin{array}{l}\text { Hadtörténelmi } \\
\text { Közlemények }\end{array}$ \\
\hline
\end{tabular}

\section{Az MH LK és a hozzá kötődő szervezet(ek) folyóiratai}

\subsection{A Haditechnika folyóirat}

A Haditechnika a Honvédelmi Minisztérium müszaki-tudományos és ismeretterjesztő folyóirata, amely a múlt, a jelen és a jövő fegyvereit mutatja be. A folyóirat a rovataiban elsősorban a hazai és nemzetközi haditechnikai fejlesztésekkel, az ürtechnikával, a hadtörténelem egyes területeinek haditechnikai vonatkozásaival kapcsolatos, valamint haditechnika-történeti tárgyú írásokat ad közre, illetve ilyen témájú könyveket ismertet hasábjain. A fél évszázada rendszeresen megjelenő Haditechnika az MTA IX. osztály Hadtudományi Bizottsága által "B" kategóriába sorolt, lektorált tudományos periodika. A színes folyóirat kéthavonta jelenik meg, A/4 formátumban, 76 oldal terjedelemben. A Haditechnika a Magyar Honvéd mellett a Honvédelmi Minisztérium egyetlen olyan folyóirata, amely nagy példányszámban jelenik meg, és kapható újságárusoknál, ezáltal egyszerre elégíti ki a piac és a tudomány igényeit, miközben a tárca kommunikációs (és

4 https://www.uni-nke.hu/kutatas/egyetemi-folyoiratok 
reklám) érdekeit is hatékonyan szolgálja, mivel 5000 példányának átlagban $90 \%$-a értékesítésre kerül.

1956. május 16-án jelent meg a Haditechnikai Szemle című folyóirat első száma, amely a Haditechnika közvetlen jogelődjének tekinthető. Az A4-es formátumú, kéthavonta megjelenő lap első felelős szerkesztője a Haditechnikai Intézet tudományos osztályának osztályvezetője volt. Az első lapszámot 1600 példányban állították elő, amely el is fogyott. A második szám már nyomdában volt, amikor az októberi harcok során a Zrínyi nyomda leállt, így ezt 1956-ban már nem nyomták ki. 1957-ben 2 szám, 1958-ban még egy szám jelent meg, de ezeket többéves szünet követte.

A Haditechnikai Szemle címü folyóirat 1967-től jelenik meg folyamatosan. 1982-ben megváltozott a megnevezése, ettől kezdve Haditechnika címen került kiadásra, és elérte a 6700 példányszámot. 1980 után a folyóirat egyre nagyobb mértékben közölte a tudományos fokozatot szerző tisztek cikkeit. A 2002. és 2003. évben 1-1 tematikus különszám is megjelent. Két részben, nyomtatott formában közreadták a Haditechnika repertóriumát 1967-1996-os és 19972001-es beosztásban. A 2000-es év jelentős fordulatot hozott a Haditechnikai Intézet életében: ekkortól a honvédelmi tárcához kötődő minőségbiztosítási (auditáció, átvétel stb.) feladatokat is itt végezték, amelynek eredményeiröl a Haditechnika folyóirat évente hivatalos közleményt bocsát ki a mai napig. ${ }^{5}$

A folyóirat 2005-ben 5600 példányban készült. A HM Technológiai Hivatal Haditechnikai Füzetek néven új - a Haditechnika folyóiratra épülő - belső kiadványt indított, ennek 7 száma készült el. Megjelent a Haditechnika 1982-1992, illetve 1993-2003 közötti számainak anyagát bemutató - az Arcanum Kiadó által megjelentetett fulltext olvasható cikkarchívum - két Haditechnika CD ROM, és elérhető volt a folyóirat internetes oldala (www.haditechnika.hu), amelyet 2010-ig üzemeltettek.

A folyóirat küldetése, hogy figyelemmel kísérje a katonai-műszaki és a hadtudományi fejlődést mind elméletben, mind gyakorlatban, annak érdekében, hogy az MH LK keretei között tevékenykedő haditechnikai kutatás-fejlesztést végző szervezet továbbra is megfelelő válaszokat adhasson a Magyar Honvédség előtt álló katonai műszaki kihívásokra. A haditechnikai kutatás-fejlesztést végző szakmai szer-

5 A „Tanúsított szervezetek” c. táblázatot rendeletileg kötelező leközölni. 
vezet - MH LK Technológiai Igazgatóság, Kutatás-fejlesztési, Tudományos és Szabványosítási Osztály - könyvtárával és szakembereivel támogatja a folyóirat tevékenységét.

A szerkesztőség az MTA IX. osztály Hadtudományi Bizottsága által megkövetelt formai és tartalmi előírásokat állandóan szem előtt tarja, így a Haditechnika folyamatosan megfelel az elért besorolásnak. A folyóirat szerkesztőbizottsága a Nemzeti Közszolgálati Egyetem, a Szent István Egyetem, illetve az Óbudai Egyetem és a Budapesti Müszaki Egyetem professzoraiból, illetve felelős beosztást betöltő főtisztekből és tábornokokból tevődik össze. A cikkeket két-két szaklektor lektorálja.

A tudomány szereplői mellett a hazai hadiipari cégeknek és a Honvédelmi Minisztérium hadiipari tevékenységgel foglalkozó részvénytársaságainak is méltó megjelenési felületet biztosít a folyóirat, amely elkötelezett a hazai hadiipar rendszeres szerepeltetése mellett. A Haditechnika lapszámonként két-két recenziót (tudományos igényü könyvek ismertetőit) közöl le a Zrínyi Kiadó legújabb szakmai témájú könyveiről, ezzel is a hadtudomány népszerűsítésének ügyét szolgálva.

Nagy áttörést jelentett a közelmúltban létrejövő szerződés a Haditechnika folyóirat és az MTA Könyvtár és Információs Központ (MTA KIK) között, így 2017 óta a könyvtár közremüködésével a folyóiratban megjelenő tudományos közlemények kapnak DOI-t (Digital Object Identifier - Digitális Objektum Azonosító), amely az elektronikus dokumentumok körében használt egyedi azonosító rendszer. Ezt a folyóiratok világszerte alkalmazzák a cikkek interneten elérhető elektronikus változatainak egyedi azonosítására és a teljes szöveg online elérhetőségének garantálására.

A cikkek bibliográfiai adatait a szerkesztőség feltölti a Magyar Tudományos Müvek Tárába (MTMT), a „pdf” formátumú teljes szöveges állomány pedig az MTA REAL repozitóriumába kerül. Itt a megjelenéstöl számított két éven belül nem nyilvános a hozzáférésük. Bevezette a folyóirat az ORCID (Open Researcher and Contributor Identifier - szerző azonosító rendszer) alkalmazását is, amellyel a 2.3. alfejezetben részletesebben foglalkozunk.

A nyomtatott terjesztés mellett a lap elektronikusan is megvásárolható a DiMag honlapján. A tárgyévet megelőző két évvel korábbi lap- 
számok csökkentett felbontású „pdf” variánsát a Zrínyi Kiadó a http://www.honvedelem.hu/ weboldalra is felhelyezi.

\subsubsection{A tulajdonosi szerepkör gyakorlója, az MH Logisztikai Központ}

Az MH LK 2013. június 24-én alakult. „Rendeltetése: a biztosított költségvetési keretek célirányos, takarékos felhasználásával folyamatosan biztosítani a HM/MH szervezetek haditechnikai eszközökkel/hadfelszereléssel történő ellátását. Végzi a központi logisztikai gazdálkodási és ellátási felelősséggel összefüggő feladatok irányítását, tervezését, szervezését és ellenőrzését. Feladata továbbá az $\mathrm{MH}$ katonai szervezetei működéséhez, harckiképzéséhez, készenlétük fenntartásához és fokozásához, a nemzetközi szerződésekből adódó feladatok teljesítéséhez a logisztikai támogatás rendjének, követelményeinek kidolgozása, a folyó tevékenység logisztikai támogatásának koordinálása. Végzi a technikai eszközök és anyagok fejlesztésével, beszerzésével, tárolásával, kezelésével, kiadásával, felhasználásával és elszámolásával, valamint azok fenntartásával kapcsolatos szakmai követelmények meghatározását, ezen feladatok végrehajtásának szervezését, irányítását és szakfelügyeletét. Feladata a müveletek logisztikai támogatásának megtervezése, a logisztikai egységek, alegységek alkalmazási elveinek kidolgozása. Feladata továbbá a hazai és a nemzetközi együttmüködés részeként a tárcaszintü haditechnikai müszaki kutatás-fejlesztési, valamint tudományszervezési feladatok végzése, minőségbiztosítási tevékenység végzése, valamint rendszertanúsítási eljárások lefolytatása, továbbá az MH Anyagellátó Raktárbázis, az MH Katonai Közlekedési Központ és az $\mathrm{MH}$ Légijármü Javítóüzem vonatkozásában a szakmai és elöljárói felügyelet gyakorlása." ${ }^{6}$ Tekintettel arra, hogy a tárca haditechnikai kutatás-fejlesztést végző szervezeti eleme 2016-ban az MH Logisztikai Központhoz került, az MH LK vette át a Haditechnika folyóirat tulajdonosi jogkörét.

\subsubsection{Kiadói tevékenység}

A Haditechnika folyóirat kiadói tevékenységét a Zrínyi Kiadó végzi.

1951-es megalakuláskor a Zrínyi Kiadónak az volt a feladata, hogy a hadseregben folyó képzést, a politikai és felvilágosító munkát segít-

6 MH Logisztikai Központ,

http://www.honvedelem.hu/szervezet/mh_logisztikai_kozpont letöltés ideje:

2017.10.20. 
se kiadványaival. Az évek alatt többször váltott nevet: először Katonai Kiadó volt, később Zrínyi Honvéd Kiadó, majd Zrínyi Katonai Kiadó lett. A kiadványok száma évröl évre növekedett. Alapvetően a hadtudomány eredményeinek, a katonák munkáinak és harci tapasztalatainak közreadása volt a cél. A 60-as évektől a magyar katonai írók munkáinak közzététele mellett elkezdtek kiadni sorozatokat, kézikönyveket, szótárakat, lexikonokat, katonai vonatkozású szépirodalmi müveket is.

A Kiadó ma is töretlenül működik a Honvédelmi Minisztérium felügyelete és szakmai irányítása alatt, neve HM Zrínyi Térképészeti és Kommunikációs Szolgáltató Közhasznú Nonprofit Kft. - Zrínyi Kiadó. A magyar könyvkiadás igényes mühelyeként hadtudományi, hadtörténelmi, biztonság- és katonapolitikai, illetve haditechnikai témájú műveket kínál az olvasónak, köztük például a Nagy csaták és a Hősgaléria címü sikeres sorozatok legújabb köteteit, haditechnikai szakkönyveket és reprezentatív fotóalbumokat. A www.honvedelem.hu honlapon keresztül elérhetőek a Zrínyi Kiadó legújabb kiadványai és számos folyóirat is, amelyek ezekhez hasonló témákat tárgyalnak.

\subsubsection{A tárcaszintű felügyeleti szerepkör gyakorlója, a HM Mi- niszteri Kabinet Sajtóosztály}

„A HM Miniszteri Kabinet a kabinetfönök közvetlen irányítása alatt működik, és a Honvédelmi Minisztérium Szervezeti és Működési Szabályzatában jóváhagyottak alapján végzi többek közt az alábbi feladatokat:

- A Honvéd Vezérkar Főnökével együttmüködve ellátja a HM Zrínyi Térképészeti és Kommunikációs Szolgáltató Közhasznú Nonprofit Korlátolt Felelősségü Társaság (HM Zrínyi Kft.) szakmai irányításával összefüggő feladatokat;

- Végzi a HM Zrínyi Kft. Kommunikációs és Kreatív Igazgatósága gondozásában készülő termékeket készítő szerkesztőségek vezetőinek szakmai felügyeletével összefüggő feladatokat;

- Kiadja a sajtónyilvánossághoz, így különösen a forgatáshoz, a fényképezéshez és az interjú-riportkészítéshez szükséges engedélyeket, beszerzi a különleges besorolású szervezetekre érvényes engedélyeket." 7

7 HM Miniszteri Kabinet, http://www.kormany.hu/hu/honvedelmiminiszterium/hirek/hm-miniszteri-kabinet letöltés ideje: 2017.10.20. 
A HM Sajtóosztály feladatkörébe tartozik továbbá, hogy a Minisztérium összes nyomtatott és elektronikus folyóirata felett szakmai felügyeleti tevékenységet gyakoroljon.

\subsection{A Katonai Logisztika folyóirat}

Dobó Péter nyá. vezérőrnagy szavait idézzük, aki a Katonai Logisztika folyóirat első számában ezt írta „Beköszöntő”-jében:

„Az anyagi-technikai szolgálat 1990-ben történő létrehozása óta egyre nagyobb igény van az elméleti és gyakorlati kérdések, problémák tudományos igényü megválaszolására, a szakmai feladatok szellemi támogatására. A „hivatalos” rendben a szóbeli vagy írásbeli szakmai előadások, vélemények, vitaanyagok nem jutottak el mindenkihez. Ez a gondunk az eltelt időszakban mindinkább növekedett, melynek megoldásán úgy véltük, egy rendszeresen megjelenö központi szakmai kiadvány (folyóirat) sokat segíthetne.

Néhány „nekifutás” után az MH anyagi-technikai föcsoportfőnök (MH ATFCSF) MH pk. helyettes kezdeményezésére, az MH parancsnok támogatásával, a MK honvédelmi miniszterének engedélyével 1993. évtől önálló szakmai kiadvány indulhat útjára."8

Így született a Katonai Logisztika folyóirat, amely kezdetben az Anyagi-Technikai Biztosítás alcímet viselte, mivel a „logisztika”, mint fogalom, a hadseregen belül még csak nagyon szük körben volt ismeretes, és az „anyagi-technikai biztosítás” volt használatban.

Még egy idézet a fenti „Beköszöntő”-ből:

„Folyóiratunkat a korábban közkedvelt „Hadtápbiztosítás” címü kiadvány jogutódjának tekintjük."

Az idézetekböl nyilvánvaló, hogy szervezeti változtatások következménye az új folyóirat. Az előd „Hadtápbiztosítás” a Magyar Néphadsereg Hadtápfönökségének kiadványa volt, amely a szervezet átalakításával együtt megszűnt. Az újonnan létrehozott $\mathrm{MH}$ AnyagiTechnikai Főcsoportfőnökség a hadtáp mellett a technikai ágazatok jelentős részét is magában foglalta. A technikai ágazatok korábban vagy az alkalmazói fönökségek részét képezték (pl. MH Repülőfönökség, HVK Híradófőnökség stb.), vagy önálló technikai fönökség-

8 Dobó Péter: Beköszöntő, Katonai Logisztika 1993/1. szám 3. o.

9 Uo. 3. 0. 
ként (pl. MH Fegyverzet-technikai Főnökség) müködtek. Ezek a szervezetek is rendelkeztek különböző belső kiadványokkal, amelyekben az alkalmazói és a logisztikai vonatkozású cikkek egyaránt helyet kaptak. Nem véletlen a jogelődválasztás, a tisztán logisztikai jellegü kiadvány a „Hadtápbiztosítás” volt.

A „Beköszöntő"-ben több olyan gondolat is megjelent, amely a folyóirat későbbi sorsára is meghatározó jelentőséggel bírt. Csak a legfontosabbakat kifejtve:

- Az akkori felsőszintű logisztikai szervezet vezetése szükségét érezte annak, hogy megossza problémáit, és lehetőséget biztosítson saját munkatársai és külső szakértők számára véleménynyilvánításra;

- Felismerte, hogy léteznek megoldásra váró problémák, amelyek kezelését a szervezeti struktúra és annak belső müködési rendje önmagában nem garantálja;

- A vezetés igényelte szélesebb, hozzáértő szakértői kör közreműködését e kérdések rendezésére;

- Felismerte, hogy a feladatok tisztázása, megoldása tudományos elmélyültségű elemzést kíván.

Ezek voltak az új folyóirat létrehozásának legfőbb indítékai. Egyben ezek játszották a fő szerepet a kiadvány további sorsát illetően. Amikor volt olyan logisztikai szervezet, amelynek vezetői fontosnak tartották a fenti szempontokat, jól működött a folyóirat, amikor nem ismerték fel ennek jelentőségét, szenvedett a kiadvány.

A szerkesztőbizottság az akkori szakmai vezető szervek vezetőiből, a Zrínyi Miklós Katonai Akadémia illetékes tanszékvezetőiből, a haderőnemek anyagi-technikai szervezeteinek vezetőiből alakult. Első elnöke Dobó Péter vezérőrnagy, az $\mathrm{MH}$ anyagi-technikai föcsoportfőnök helyettese volt. Az évek során létszámában bővült, összetételében is változott, de a tagokat hasonló elvek alapján választották ki.

A cikkek szerzői is gyakran ugyanebből a körből kerültek ki, de a különböző szakterületek vezetői, munkatársai, sőt „külsősök” is publikáltak a lapban. 
A folyóirat 1993 és 2007 között zökkenőmentesen, azonos elvek mentén müködött annak ellenére, hogy ez időszak alatt több átszervezésen ment keresztül a „logisztika”. Először 1997-ben megszűnt az MH Anyagi-Technikai Főcsoportfőnökség, helyette létrehozták az MH Logisztikai Főigazgatóságot (MH LFI), mint a logisztika csúcsszervezetét. Később, 2001 elején megszünt az MH LFI, és új logisztikai vezető szerv született MH Összhaderőnemi és Logisztikai Támogató Parancsnokság (MH ÖLTP) néven. Az MH ÖLTP létrehozásával egyfajta nyitás indult a folyóirat vonatkozásában. Amíg az MH ATCsFség és az MH LFI a folyóiratot „belső kiadványként” jelenttette meg, az MH ÖLTP idején már nincs a „belső” jelző, sőt egy év múlva a 2002/1. szám már ISSN-nel (International Standard Serial Number, időszaki kiadványok nemzetközi azonosítója) is rendelkezik, tehát elkezdődött az a folyamat, amelynek célja volt, hogy kilépjen a hazai, illetve nemzetközi tudományos színpadra. A lap terjesztése 2004. év végéig megőrizte „katonás” jellegét (nyilvántartási szám, elosztó stb.), a 2005/1. szám már ettől is mentes, nyílt folyóirattá vált. Dr. Gáspár Tibor a lap 20. évfordulójára írt visszaemlékezésében így ír erről:

„Ez a - katonai kiadványok között speciális szakmai, a katonai logisztika aktuális problémáival, fejlesztésével foglalkozó - periodika az átalakulásokat követve az elmúlt években folyamatosan megújult. A korábbi, a Magyar Honvédségen belüli nyilvántartási számmal ellátott terjesztést elhagyva (amelyre a honvédséget érintő témák ún. „nem nyilvános” kezelése miatt volt szükség!), „nyillt” folyóirattá vált. Ennek köszönhetően folyamatosan nő a polgári életből azon logisztikusok száma, akik a lapban szeretnék cikkeiket megjelentetni. A folyóirat elektronikus példányai 2005-töl folyamatosan kint voltak a Honvédelmi Minisztérium internetes honlapján is."10

A folyóirat 1993 és 2007 között évente 4 számmal jelent meg, számonként 18-22 cikket tett közzé, és több különszám is napvilágot látott. A 2007. év komoly változást hozott a kiadvány életében, ismét átalakították a logisztikai rendszert. Megszűnt az MH ÖLTP, és az új szervezetben, a HM Fejlesztési és Logisztikai Ügynökségnél (HM FLÜ) eltolódott a súlypont a logisztikáról. Meglátszott ez a folyóiraton is. 2007-ben, mint már korábban említettük, még negyedévenként jelent meg a lap, 2008-ban és 2009-ben azonban már csak félévente és csak elektronikus változatban, 2010-ben és 2011-ben pedig csak 1-1 alkalommal. Csökkent az egyes számok terjedelme is.

10 Gáspár Tibor: 20 éves a Katonai Logisztika folyóirat; Katonai Logisztika 2013/1. szám 9. o. 
Bár 2011-ben is csak egyszer jelent meg a kiadvány, ez a folyóirat újjászületésének éve. A logisztikai struktúrát ugyanis ismételten átalakították, a HM Fegyverzeti és Logisztikai Ügynökség megszűnt,

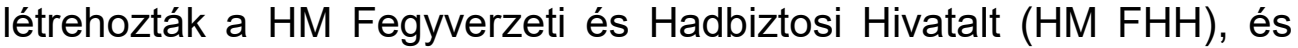
újra megalakították a HVK Logisztikai Csoportfönökségét. A két új szervezet vezetése az Összhaderőnemi Parancsnokság logisztikai vezetőjével karöltve elhatározta, hogy „újjáélesztik” a Katonai Logisztikát. Ez sikeresen megtörtént, hiszen 2012-ben már negyedéveként jelent meg a kiadvány, azonban 2013 nyarán újabb átszervezés következtében megszűnt a $\mathrm{HM} \mathrm{FHH}$, a megmaradt és az újonnan létrehozott szervezetek egyike sem vállalta fel a folyóirat szerkesztését. A lap „civil szervezethez”, a Magyar Katonai Logisztikai Egyesülethez került. A létrehozott új logisztikai csúcsszervezet, az MH Logisztikai Központ (MH LK) parancsnoka és munkatársai a megalakítástól aktív részesei voltak a lap szerkesztésének, az MH LK a lap nyomdai közzétételét is lehetővé tette, munkatársaik aktívan éltek a publikációs lehetőséggel.

A kiadványért viselt közös felelősség, az aktív állomány egyre szélesebb körének bevonása a szakmai publikációk írásába, továbbá a katonai logisztika aktuális kérdéseiről szóló gondolatok, elképzelések növekvő részesedése a periodikában, logikusan vetette fel annak igényét, hogy a Katonai Logisztika tulajdonjoga legyen megosztva a Magyar Katonai Logisztikai Egyesület és az MH LK között. Ez az 50$50 \%$-os, mindkét fél részére előnyös megosztás 2017 májusában, a Honvédelem napja alkalmából rendezett ünnepi megemlékezés keretében hivatalosan is megtörtént.

A szerkesztőbizottság létszáma jelentősen bővült, amiben képviselteti magát minden fontos katonai és polgári logisztikai szervezet, továbbá jelentős erövel járulnak hozzá a közös munkához a Nemzeti Közszolgálati Egyetem katonai logisztikai kérdésekkel foglalkozó szervezetei is.

A korábbi években elért eredményekröl Dr. Gáspár Tibor már előbb is idézett cikkében így ír:

„Nagyon fontos megemlíteni a folyóirat tudományos elismertségét. Bátran kijelenthető, hogy a lap - mint lektorált tudományos folyóirat jelentős szakmai tekintélyt vívott ki magának. A benne publikálók a legkülönbözőbb polgári és katonai felsőoktatási intézményekben folytatott tanulmányaik vagy tudományos tevékenységük során az itt megjelent írásukra hivatkozhatnak, illetve mások a megfelelő hivatko- 
zással az egyes szerzők anyagát felhasználhatják. $A$ folyóirat szerepel az MTA és a Nemzeti Közszolgálati Egyetem (NKE) Hadtudományi Doktori Iskola „Publikációs Listáján”. A folyóirat - tudományos elismertsége révén - jelentős megnyilvánulási lehetőséget biztosít az NKE és az utóbbi időszakban néhány, a polgári felsőoktatási intézmény posztgraduális képzésében résztvevők részére. Ezt az elismertséget a folyóirat színvonalas tudományos cikkek, dolgozatok, müvek következetes megjelentetésének köszönheti. A színvonalat pedig azzal tudja biztosítani, hogy a folyóiratnál tudományos fokozattal rendelkezőkböl álló, külön Lektori Bizottság müködik, amelynek tagjai a beérkezett müvek megjelenés előtti lektorálását elvégzik."11

A Katonai Logisztika folyóirat szerkesztőbizottsága képviselteti magát az MTA IX. Gazdaság- és Jogtudományok Osztálya Logisztikai Osztályközi Állandó Bizottságában (MTA LOÁB). A Bizottság alelnöke Prof. Dr. Turcsányi Károly nyá. mk. ezredes, az MTA doktora, a Bizottság hadtudományi területröl delegált tagjai: Dr. Tóth Rudolf dandártábornok, állandó meghívottak: Dr. Szenes Zoltán nyá. vezérezredes, Dr. Keszthelyi Gyula nyá. mk. dandártábornok, Dr. Hegedús Ernő mk. örnagy. ${ }^{12}$ Az MTA LOÁB ülésein folyamatosan nyomon követik a tudományos folyóiratok besorolásának kérdéskörét is.

\subsection{Karbantartalak, az MH Anyagellátó Raktárbázis csapatúj- ságja $^{13}$}

A csapatújság a lapkiadások rendszerében sajátos helyet foglal el, hiszen elsődleges célja egy szük közösség, az adott katonai szervezet tagjainak megszólítása. Korlátozott körü terjesztése mellett példányszáma is csekély, témái is egy szük közönséget érintő, érdeklő témákra szűkülnek. Mindezek ellenére komoly értéket képvisel, amennyiben sikerül betöltenie feladatát, a csapathagyományok megteremtését és ápolását, és egyfajta kohéziós erőként lép fel a személyi állomány körében is megfelelő alapot teremtve a későbbi kutatások számára.

11 Gáspár Tibor: 20 éves a Katonai Logisztika folyóirat; Katonai Logisztika 2013/1. szám 8. o.

12

Turcsányi Károly: Logisztika az akadémiai tudományos közéletben - megalakult az MTA Logisztikai Osztályközi Állandó Bizottsága, Katonai Logisztika 2012. évi 4. sz., illetve Tájékoztató - Információ: Újraválasztották a Magyar Tudományos Akadémia Logisztikai Osztályközi Állandó Bizottságát, Katonai Logisztika 2015. évi 1. sz. 305. o. nek adatszolgáltatása alapján. 
A Mátyásföldön települő MH Haditechnikai Ellátó Központ bázisán létrehozott MH Logisztikai Ellátó Központ (MH LEK) dolgozói a napi tevékenységük során használták az intranet hálózatot, amelyen a katonai szervezet saját honlapot is fejlesztett. A különböző információs és munkafelületek mellett a honlap „Kultúra” rovattal is rendelkezett, amely nagy olvasottságnak örvendett, hiszen ott nyílt lehetőség hasznos, érdekes, olykor közhasznú információk közzétételére, programajánlatra, figyelemfelhívásra. Különösen fontos tény ez egy részeiben, alegységeiben, raktáraiban széttagolt, országos elhelyezkedésü szervezet számára. Az elektronikus „Kultúra” rovatból történő kilépés és a nyomtatott formában való megjelenés gondolata többször felmerült, de megvalósulása egy olyan parancsnokváltáshoz köthetö, amikor az új, egyszemélyi felelős a parancsnoki gondoskodást kiterjesztve szorgalmazta csapatújság megjelentetését. Tette ezt azért is, mert az alakulat, ahonnan az új parancsnok érkezett, rendelkezett sikeres kiadvánnyal, és látta annak pozitív hatásait.

Szerkesztőbizottság alakult a parancsnokhelyettes vezetésével, amelyben helyet kapott a kommunikációs tiszt mellett a parancsnoki segítő és két agilis katona is, akik már az intranetes felületen is eredményesen tevékenykedtek. A szerkesztőbizottság elnöki tisztét a törzsfőnök töltötte be. Az MH LEK csapatújságja „Figyelek” címmel, a parancsnoki elvárásnak megfelelően, először 2011. december elsején jelent meg, a Logisztikusok napja tiszteletére. Az A4-es méretü, színes borítóval és fekete-fehér belívekkel nyomtatott, 8 oldalas kiadvány 150 példányban látott napvilágot. $A$ tördelés, nyomdai előkészítés és nyomtatás munkáit az MH Hadkiegészítő és Központi Nyilvántartó Parancsnokság nyomdájában végezték. A havonta 8-12 oldalon megjelenő lapot három évfolyam és 20 lapszám (valamint tematikus különszámok) után 2013 júliusában vehették kézbe az olvasók utoljára.

A lap elnevezéséhez híven (kis szójátékból adódóan „Figye-LEK”), elsősorban figyelemfelhívó kívánt lenni, rávilágítani az MH LEK eseményeire. A megjelenő írások gerincét képezték az aktualitások, a csapatélet eseményei, hírei, beszámolók különböző gyakorlatokról, sporteseményekről, a bázisokon történt eredményekről. Sajátos szerepet kaptak a személyi hírek: elöléptetésekről, elismerésekröl, dolgozók gyermekeinek születéséről, halálozásról. Egy csapatújság elengedhetetlen részét kell képeznie az állomány számára a hosszú szolgálatok során is felüdülést kínáló érdekességek, rövid hírek, kulturális információk közlésének. Így került sor cikksorozatokban egyházi és állami ünnepeink bemutatására, mátyásföldi vonatkozású, 
érdekes történelmi személyek életének bemutatására (Kicsoda ez az ember címmel), és bajtársaink bemutatkozására (Emlékek, sorsok, katonatörténetek címmel), valamint a szolgálatteljesítés és napi munka mellett tevékenyen élö, alkotó kollégák bemutatására (Szolgálaton kívül címmel). Mindezek mellett az MH LEK munkatársainak írásai jelentek meg a fontos beszerzési programokról is, így például a Gépjármü Beszerzési Programról, a C2 képesség kialakításáról, a modern lőfegyverekröl stb. Alkalmilag jelentkeztek az MH Egészségügyi Központ tájékoztatói, esetleg felhívásai egy-egy közérdekü kérdésben, csakúgy, mint a Pénzügyi Referatúra aktuális pénzügyi tájékoztatói.

A logisztikai rendszer átalakításának következtében 2013-ban szervezeti változások történtek, amelyek nyomán az MH Logisztikai Ellátó Központ és az MH Veszélyesanyag Ellátó Központ összevonásával létrejött az $\mathrm{MH}$ Anyagellátó Raktárbázis (MH ARB). Az új parancsnok is felismerte a csapatújságban rejlő lehetőséget, és a parancsnoki keretből továbbra is biztosította az ingyenes havilap költségeit, a papír és a nyomólemezek kiadásait. Többször felmerült a csupán elektronikus megjelentetés elképzelése, de a nyomtatott sajtó varázsa és a személyi hírek érintetteinek igénye - hogy eltehessék a róluk szóló lapszámot „örök” emlékül - meggyőzte a parancsnokot és a szerkesztőket a nyomdai előállításról. A szerkesztőbizottság összetételében nem, de tagjaiban némileg megváltozott, és az immár 300 példányban havonta megjelenő újság elnevezése „Karbantartalak” lett, hogy kövesse a hagyományt, és hordozza a csapat rövidítését, az MH ARB betüit. Az első, 2013. szeptemberi megjelenés óta több mint 40 számmal és jó néhány különszámmal jelentkező újság továbbra is színes külsővel és fekete-fehér belső lapokkal, 16-18 oldaIon jelenik meg. A kialakult állandó és időszakos rovatok mellett olyan érdekes mini sorozatok is napvilágot láttak, mint az MH ARB katonai képességeit bemutató vagy a "Csapataink névadóiról” szóló életrajzi sorozat, és az „Art Bázis” címü cikkek, melyek a csapat művészeiről és alkotásaikról szóltak. Az országban található haditechnikai parkok is sorozatban kerültek bemutatásra, hogy kedvet ébresszenek egyegy kirándulás szervezésére. A szórakoztató blokkban új elemként jelentkezett a csapatra aktualizált keresztrejtvény megjelentetése, és változatlanul helyet kaptak Tomena György karikaturista munkái.

Az elöljárók és az olvasók visszajelzései alapján bátran kijelenthető, hogy a sok-sok éves hagyománnyal rendelkező csapatújságok valóban képesek betölteni feladatukat és összetartó erővé válni, amelyre a különböző feladatok, a területi és földrajzi széttagoltság 
miatt szükség van, és így a morál, a csapat iránti lojalitás növelésével hozzájárul az egységes arculat kialakulásához.

\section{Tudománymetriai szempontok}

\section{1. $A z$ MH LK folyóiratai és a tudománymetria kapcsolata ${ }^{14}$}

Abban az időben, amikor a kéziratokat még valóban kézzel írták, a tudomány megítélése meglehetősen szubjektív volt. Azt, hogy egy kutató vagy kutatás mennyire volt „tudományos”, igen nehezen lehetett mérni. A számítógépek és a számítógépes adatbázisok azonban ezen a területen is jelentős változást hoztak a múlt század utolsó harmadától, és lehetővé vált, hogy egy kutató vagy egy munka tudományos értéke objektívnek elfogadott mérőszámok alapján kerüljön megítélésre. Mára ez a tevékenység annyira része a tudományos életnek, hogy a „tudományosság” statisztikus mérése és értékelése maga is egy önálló tudománnyá vált, ez a tudománymetria (scientometrics).

A tudománymetria abszolút és relatív mérőszámokon alapszik. ${ }^{15}$

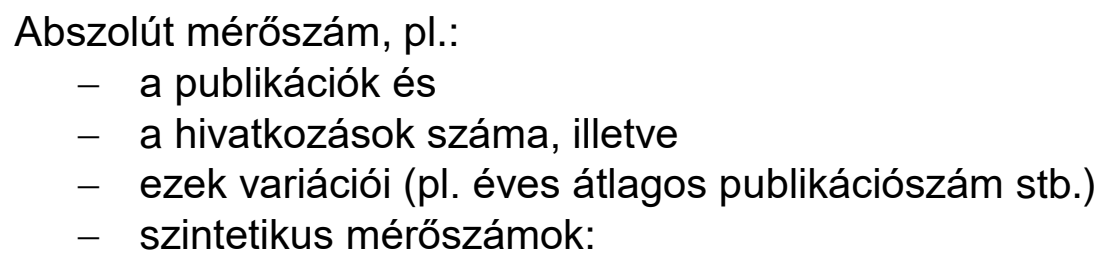

Abszolút mérőszám, pl.:

- a publikációk és

- a hivatkozások száma, illetve

- ezek variációi (pl. éves átlagos publikációszám stb.)

- szintetikus mérőszámok:

- az impakt faktor, amely a folyóiratra vonatkozó mérőszám, a folyóirat két évfolyamának átlagos idézettsége a harmadik évben;

- a Hirsch-index, amely a szerzők idézettségére vonatkozó mérőszám (pl. 3 az érték, ha a szerzőnek legalább 3 olyan cikke van, amely legalább 3 független hivatkozással bír).

Relatív mérőszámok, pl.:

- az egy publikációra eső átlagos hivatkozásszám.

14 Végvári Zsolt, MH LK Technológiai Igazgatóság, Kutatás-fejlesztési, Tudományos és Szabványosítási Osztály, kiemelt főmérnök főtiszt kutatásai alapján.

15 SZTE szerzői eszköztár, http://szerzoknek.ek.szte.hu/amibensegitunk/tudomanymetria/ a letöltés ideje: 2017.09.26. 
A fentiekből látszik, hogy a „tudományosság” mérésekor messze a legfontosabb a hivatkozások száma és típusa.

Akik nem rendelkeznek szükséges digitális kompetenciákkal, azok elöbb-utóbb „kikopnak a tudományos világból”, még akkor is, ha egyébként valóban értékeset alkotnak. Nem kétséges, hogy a tudományos életben valóban komoly verseny folyik, és ez nem csupán ismertségről és elismertségről szól. A hadtudomány, illetve a katonaiműszaki tudomány területén a több mint tucatnyi magyar periodika többnek tűnik, mint amennyit egyenletes értékü tartalommal időrölidőre meg lehet tölteni.

A számítógépes adatkezelés sokat segít a nyilvántartásban, a források, illetve hivatkozások keresésében, a tudománymetriai értékelések készítésében, azonban ez a rendszer sem mondható általánosan objektívnek. Például egy történész, társadalomtudós évente több cikket is meg tud jelentetni újabb és újabb kutatási eredményeiről, míg egy kutatómérnöknek gyakran akár éveket is várnia kell egy-egy újabb publikálható tudományos eredményre. Az előbbiek könnyebben eljuthatnak a 100 fölötti publikációs számhoz, így a magas Hirschindexhez is, míg az utóbbiak nehezebben kerülnek néhány tucatnál magasabb publikáció fölé, amely egyben alacsonyabb Hirsch-indexet is eredményez. Így aztán nagyon nehéz megállapítani, hogy ki a „nagyobb tudós", aki az I. világháborút vagy napjaink társadalmi változásait kutatja, a matematikus, aki a számsorozatokat vizsgálja, vagy az, aki az anyagtudományok terén jeleskedik. Tudományos folyóiratok értékelésekor hasonló jellegű problémákkal is találkozhatunk. Így válhatnak különböző szakterületek tudósai egymás konkurenseivé például a habilitáció, az akadémiai doktori cím, az MTA tagság elérése érdekében folytatott tevékenységük során. ${ }^{16}$

Ebben a kontextusban vizsgáljuk meg az MH LK gondozásában megjelenő periodikákat, illetve azok tudományos megítélésén való javítás lehetőségét. $E$ tekintetben a Karbantartalak kivételes, mivel a léte egyáltalán nem függ a tudományos megítélésétől. Amennyiben az elöljáró által megvan a támogatás, és rendelkezésre állnak a valóban szerény szükséges források, csak azon múlik a lap fennmaradása, hogy a szerkesztőgárda képes-e a megfelelő témákkal fenntartani az állomány figyelmét, a mai információtól hemzsegő világban. A kiadványnak „másodlagos tudományos értéket” tulajdonítunk, mivel a

16 Gőcze István: A mértékadó hazai hadtudományi folyóiratok diszciplináris impaktfaktorának meghatározása; Hadtudományi Szemle 2016. IX. évf. 2. szám. 
lap jelenleg nem tudományos tartalmú, azonban későbbi kutatások reális alapját tudja képezni.

A Haditechnika folyóirat jelentős tudományos érték a tárca, illetve az MH LK tulajdonában. Tény, hogy a Haditechnika a legmagasabb elérhető nyomdai minőségben készül, így a könyvtárak számára is maradandó érték. Emellett az újságosoknál több ezren meg is veszik a lapot. Ez a kettősség olyan kihívás, amivel egyetlen másik katonai lapnak sem kell megküzdenie. Mivel a Minisztérium tulajdonában lévő tudományos kiadványokkal szemben a Haditechnikát nagyszámú laikus olvasó is a kezébe veszi, a szerkesztőknek óvatosan kell egyensúlyozni a tudományosnak minősíthető, illetve az ismeretterjesztő írások között. Jelenleg ezt a küldetést sikeresen végzi a lap, hiszen a tudományosságot nem elsődlegesként kezelő Regiment, Aranysas és Kaliber magazinokkal egy polcon árulják (és adják el), miközben komoly tudományos értéket is képvisel.

A Haditechnika tudományosság tekintetében elismert lap, viszont az negatív tény, hogy az interneten csak korlátozottan van jelen. A folyóirat nemrég létrehozott Facebook oldala jelentős előrelépésnek tekinthető, ugyanakkor az mára ugyanolyan „de facto” kötelező kelléke egy lapnak, mint az ISSN (International Standard Serial Number, időszaki kiadványok nemzetközi azonosítója).

Amennyiben egy-két éven belül nem kerül fel az internetre egy olyan szabadon elérhető és kereshető archívum, ami minimum húsz évre visszamenőleg tartalmazza az egy-két évesnél régebbi valamennyi cikket, az károkat okozhat a lap tudományosságának megítélésében (pl. kereshetőség, idézhetőség). A DiMag Kft.-vel kötött elektronikus lapterjesztési szerződés csak részben képes pótolni ezt a hiányosságot. $^{17}$

A Katonai Logisztika - célközönségét tekintve - inkább hasonlít az egyetemi lapokhoz, mivel sokkal szükebb olvasóközönséget szólít meg, és máig sikeresnek tekinthető. A lap igen jól kereshető és bárki által szabadon elérhető archívummal rendelkezik, amely meg is látszik a Google-találatokon, ha valaki egy kimondottan szakmai témára keres rá. ${ }^{18}$

17 A Windows és Android alkalmazásboltokból letölthető olvasószoftver applikációk felhasználásával.

18 Katonai Logisztika online letölthető számai, http://www.mkle.net/katonailogisztika/ a letöltés ideje: 2017.11.16. 


\subsection{A jövő lehetőségei: hivatkozáskezelő programok és a CrossRef DOI}

A javaslataink megfogalmazása előtt tegyünk egy kis kitérőt a könyvtárak és digitális adatbázisok világába. Egy átlagos tudományos cikkel szemben minimum elvárás a legalább tucatnyi hivatkozott forrásmű feltűntetése. Egy doktori értekezés esetében ez az érték 100 vagy akár 200 is lehet. Ilyen mennyiségü forrásmunka kezelése manuálisan nyilvánvalóan nem lehetséges, ezért a jövendő tudós nemzedék rá van kényszerítve, hogy „gépesítse” a hivatkozásai kezelését. A korszerü forráskezelő szoftverek, mint pl. a Citavi vagy a Zotero használata szinte elvárás. Ezek a szoftverek egy adatbázisban tárolják a szerző által ismert és feldolgozott (vagyis hivatkozott) müveket. Ezt az adatbázist pedig három módon lehet feltölteni:

- kézzel (vagyis begépeljük a szerző nevét, a címet stb.);

- egy böngésző plug-in használatával egy kattintással elmentjük a releváns internetes oldalakat (a HTML metaadatok az esetek többségében tartalmazzák a szerző nevét, a címet stb.);

- egy adatbázisból hívjuk le a szükséges adatokat egy egyedi azonosító, vagyis könyvek esetében pl. az ISBN (International Standard Book Number, Szabványos Nemzetközi Könyvazonosító Számsorozat), cikkeknél jellemzően a DOI (Digital Object Identifier, Digitális Objektum Azonosító) megadásával.

A DOI azonosítókat tíz ügynökségen keresztül lehet készíteni, az MTA KIK ezek közül kettő segítségével nyújt regisztrációs szolgáltatást: ezek a CrossRef (http://www.crossref.org/) és a DataCite (https://www.datacite.org/).

A DOI rendszer előnyei a következők:

- a DOI egyedi azonosító, segítségével könnyen és biztosan megkülönböztethetőek a hasonló címü cikkek;

- a DOI egy állandó azonosító. A cikkre lehet linkelni a DOI-n keresztül (a https://doi.org/ után az azonosítót írva), és a DOI-s linkek akkor is a dokumentumra mutatnak majd, ha az eredeti helyéről máshová költözött;

- a DOI rendszer mögött nemzetközi meta-adat tárházak vannak, amelyekből a tájékozódást segítő bibliográfiai adatokat meg lehet szerezni (egy bibliográfiai rendszerbe a leíró adatok 
begépelése vagy fájlból való importja helyett megoldható az azonosító alapján való import);

- a DOI nemzetközileg elterjedt, itthon is terjedő azonosító, a kiadók többsége alkalmazza;

- a DOI bibliográfiai rendszerekben kiválóan alkalmas lehet duplumellenőrzésre;

- az MTA Könyvtár és Információs Központ (MTA KIK) a DataCite szervezet tagjaként térítésmentesen tud DOI azonosítót biztosítani mindazon digitális objektumok (PhD dolgozatok, adatállományok, dokumentációk, esetleg folyóiratcikkek) számára, amelyek online elérhetőek és vállalják az archiválást egy, a hosszú távú megőrzésüket és szolgáltatásukat biztosító repozitóriumban, és melyekről a kiadó megfelelő leíró adatokat szolgáltat. ${ }^{19}$

Tekintettel a hivatkozáskezelő szoftverek várható térnyerésére, a jövőben jobb bibliometriai mutatókat fognak elérni azok a publikációk, amelyeknek CrossRef-es DOI-jai vannak, mivel ennél az ügynökségnél kötelező az irodalomjegyzékben linkként elhelyezni a hivatkozott közlemények DOI-át, ha azt szintén a CrossRef-nél regisztrálták más kiadók. ${ }^{20}$ A linkelés elősegíti a hivatkozott irodalom olvasottságát, növeli az idézettséget, és az azonosítók révén lehetővé válik a hivatkozások automatikus gyüjtése.

\subsection{Az ORCID}

Az ORCID (Open Research and Contributor Identifier) egy nemzetközileg általánosan elfogadott szerző azonosító kód, amely biztosítja a kutató egyértelmű azonosíthatóságát. Használatával elkerülhető az azonos, gyakori nevű szerzők munkásságának keveredése, a különböző névalakok használatából adódó vagy névváltozásból eredő problémák, megkönnyíti az automatikus adatfeldolgozást az indexelő adatbázisokban. ${ }^{21}$

19 Holl András: Információk a DOI Azonosítókról

https://www.mtmt.hu/sites/default/files/doi_ism.pdf letöltés ideje: 2017.11.09.

Dudás Anikó: A tudományos kiadási eljárás kéziratváltozatainak terminológiája.

Tudományos és Müszaki Tájékoztatás, 2013. évi 11-13. sz. 466. 0.

21 MTA Open Acces honlapja,

http://openaccess.mtak.hu/index.php/kiadoknak/orcid

letöltés ideje: 2017. 11. 16. 
A kód 19 karakterből áll, 4x4 számjegy és 3 kötőjel. Az ORCID közösségébe egyének és szervezetek is regisztrálhatnak. A bejelentkezéskor lehetőség van az adatvédelemmel kapcsolatos beállításokra is, így minden szerző maga döntheti el, hogy mennyit kíván megosztani az adatai közül. A csatlakozott szervezetek között olyan cégeket találunk, mint a Wiley-Blackwell, az Elsevier, a Nature Publishing Group, a Thomson Reuters vagy a CERN. Az is tény, hogy egyre több kiadó teszi kötelezővé az ORCID használatát, ennek megadása nélkül nem is fogadnak be kéziratot.

Az ORCID lehetővé teszi a kommunikációt és a hitelesítést a különböző adatbázisok között. Használata egyre inkább terjed Magyarországon is. Az elsőként alkalmazó MTMT mellett már a Magyar Folyóiratok Tartalomjegyzékének Kereshető Adatbázisa (MATARKA) rendszerébe is feltölthetök az ORCID-ok.

Az ORCID regisztrációs oldala: http://orcid.org/ tudományos kutatók, egyetemi oktatók stb. adatbázisa. Ezek az azonosítók a Nemzetközi Szabványos Névanozosító (International Standard Name Identifier, ISNI) részhalmazát képezik ${ }^{22}$. A szerzők ORCID-ot a http://www.orcid.org/ honlapon pár kattintással ingyen regisztrálhatnak maguknak.

\section{Összegzés}

Általánosságban elmondható, hogy a tárca magyar tudományos szférával való kapcsolattartása, a tudományos életben való részvétele, a tudomány szereplőivel (kutatóintézetek, egyetemek, Magyar Tudományos Akadémia) való közös tevékenység feltételeinek megteremtése érdekében a tárca folyóiratainak feladata, hogy:

- a tudományos kutatókat, oktatókat, egyetemi tanárokat, HM intézetekben alkalmazott kutatókat publikációs felülethez juttassa;

- a kutatási eredményeket széles körben elérhetővé tegye.

${ }^{22}$ ISNI honlapja, http://www.isni.org/ letöltés ideje: 2017. 10. 20. 
Az MH Logisztikai Központ tulajdonában lévő három folyóirat - a Haditechnika, a Katonai Logisztika ${ }^{23}$, illetve a Karbantartalak ${ }^{24}$ elemzésének eredményeképpen az alábbi következtetéseket vontuk le:

- a három lap a katonai folyóiratok három eltérő kategóriáját képviseli;

- a Haditechnika, illetve a Katonai Logisztika a Magyar Tudományos Akadémia (MTA) IX. osztály Hadtudományi Bizottsága által „B” tudományos kategóriába sorolt kiadványok, amelynek meghatározó jelentősége van az MH LK-nál felállított tudományos kutatóhely müködtetése szempontjából is;

- a Katonai Logisztika a folyóirat teljes korábbi megjelenését felölelö elektronikus archívummal rendelkezik;

- a Haditechnika folyóiratban megjelenő cikkek DOI-val rendelkeznek, emellett a folyóirat szerkesztősége elvárja a szerzőktöl az ORCID használatát;

- a Katonai Logisztika folyóirat szerkesztőbizottsága képviselteti magát az MTA IX. Gazdaság- és Jogtudományok Osztálya Logisztikai Osztályközi Állandó Bizottságában, amelynek ülésein folyamatosan nyomon követik a tudományos folyóiratok besorolásának kérdéskörét is;

- a jövő általunk ajánlott útja a hivatkozáskezelő programok (forráskezelő szoftverek) és a CrossRef DOI bevezetése mindkét tudományos lapnál;

- a CrossRef-nél minden egyes DOI regisztrációjáért fizetni kell nettó 1 dollárt, ennek fejében minden cikk automatikusan bekerül egy olyan nemzetközi adatbázisba, amelyben a hivatkozáskezelők keresnek, és lehetővé válik a hivatkozások automatikus lekérdezése is.

A fentiekre való tekintettel javasoljuk mindhárom lap további fenntartását. Az MH LK tulajdonában álló és az MTA által kategorizált la-

23 50-50\%-os tulajdonmegosztásban az MH LK és a Magyar Katonai Logisztikai Egyesület között.

24 MH ARB, az MH Logisztikai Központ alárendelt szervezetének csapatújságja. 
pok tudományos elismertségének fenntartása, illetve növelése érdekében célszerünek tartjuk:

1. A Haditechnika folyóirat esetében egy legalább olyan színvonalú online publikálási felület és archívum létrehozását és folyamatos gondozását, mint amilyennel a Katonai Logisztika rendelkezik;

2. Mindkét tudományos lap esetében a cikkek CrossRef ügynökségnél történő regisztrációját, amelyet az MTA KIK biztosít, de csak a lap tulajdonosának kötelezettségvállalása után. A két lap megjelenési gyakorisága, illetve az egy számban közölt cikkek átlagos száma alapján ez éves szinten (az aktuális USD árfolyamon számolva) kb. bruttó $45000 \mathrm{Ft}$ költségvonzattal jár.

(A szerzők köszönetet mondanak Veres István nyá. ezredesnek, Végvári Zsolt alezredesnek, Bartha lldikó alezredesnek és Druzsin József századosnak, akik munkájukkal hozzájárultak ennek a cikknek a megírásához.)

\section{Források}

2010. évi CIV. törvény a sajtószabadságról és a médiatartalmak alapvető szabályairól

CrossRef DOI ügynökség honlapja, http://www.crossref.org/ letöltés ideje: 2018.02 .15

DataCite DOI ügynökség honlapja, https://www.datacite.org/ letöltés ideje: 2018.02.15

Dobó Péter: Beköszöntő, Katonai Logisztika 1. évf., 1. szám (1993)

Dudás Anikó: A tudományos kiadási eljárás kéziratváltozatainak terminológiája. Tudományos és Müszaki Tájékoztatás, 2013. évi 11-13. sz.

Gáspár Tibor: 20 éves a Katonai Logisztika folyóirat; Katonai Logisztika 21. évfolyam 1. szám (2013)

Gőcze István: A mértékadó hazai hadtudományi folyóiratok diszciplináris impaktfaktorának meghatározása; Hadtudományi Szemle IX. évf. 2. szám (2016) 
Hajdú Ferenc: 50 éves a Haditechnika folyóirat; Haditechnika 50. évfolyam 1. szám (2016)

HM Miniszteri Kabinet, http://www.kormany.hu/hu/honvedelmiminiszterium/hirek/hm-miniszteri-kabinet letöltés ideje: 2017.10.20.

Holl András: Információk a DOI Azonosítókról, https://www.mtmt.hu/sites/default/files/doi_ism.pdf letöltés ideje: 2017.11.09.

Honvdelem.hu, http://www.honvedelem.hu/ letöltés ideje: 2018.02 .15

https://www.uni-nke.hu/kutatas/egyetemi-folyoiratok

ISNI honlapja, http://www.isni.org/ letöltés ideje: 2017. 10. 20.

Katonai Logisztika honlap, http://www.mkle.net/katonai-logisztika/ letöltés ideje: 2015.02 .15

MH Logisztikai Központ, http://www.honvedelem.hu/szervezet/mh_logisztikai_kozpont, letöltés ideje: 2017.10.20.

MTA KIK, A modern folyóirat-kiadás eszközeiről szóló konferencia, http://openaccess.mtak.hu/index.php/esemenyek/7-a-modernfolyoirat-kiadas-eszkozei, a letöltés ideje: 2017.11.09.

MTA Open Acces honlap, DOI tájékoztató, http://openaccess.mtak.hu/index.php/kiadoknak/doi/ letöltés ideje: 2017. 10. 21

MTA Open Acces honlap, ORCID tájékoztató:http://openaccess.mtak.hu/index.php/kiadoknak/orcid letöltés ideje: 2018.02.15

ORCID honlap, http://www.orcid.org/ letöltés ideje: 2017. 11. 16.

Szabó József (szerk.): Hadtudományi Lexikon, Magyar Hadtudományi Társaság, Budapest, 1995. Haditechnika, Katonai Logisztika szócikkek 
SZTE szerzői eszköztár, http://szerzoknek.ek.szte.hu/amiben-segitunk/tudomanymetria/ a letöltés ideje: 2017.09.26.

Tájékoztató - Információ: Újraválasztották a Magyar Tudományos Akadémia Logisztikai Osztályközi Állandó Bizottságát, Katonai Logisztika 2015. évi 1. sz. (2015)

Turcsányi Károly: Logisztika az akadémiai tudományos közéletben - megalakult az MTA Logisztikai Osztályközi Állandó Bizottsága, Katonai Logisztika 2012. évi 4. sz. (2012) 